\title{
JACKSON COUNTY'S TEMPORARY MISSISSIPPI RIVER
}

\author{
By John R. Adney, Miles, Iowa
}

Iowa has long been known to be one of the important areas in the world for the study and interpretation of glacial deposits of Pleistocene age. More than sixty-five y ears ago, T. C. Chamberlin, W. J. McGee, Frank Leverett, Samuel Calvin and other students of glacial geology, found within the state and adjoining states, tills and related materials which were interpreted to have been made in five glacial stages and four interglacial stages.

When I first began geological field work in Jackson County, one prominent topographical feature which attracted my attention was the broad valley which is at present occupied by the northward flowing Deep Creek, about five miles west of the town of Miles.

I followed the valley southward, noting the terraces and deposits which appeared to be of glacial origin and concluded that the valley must have been made by a glacial stream of considerable extent. To satisfy my curiosity I began an investigation which was to require a substantial part of my time for many years.

Previous field work had been devoted to invertebrate paleontology and stratigraphy and I possessed little knowledge of the Pleistocene glaciers. My request for assistance directed to Dr. A. C. Trowbridge, Professor Emeritus, Department of Geology at the State University of Iowa, was answered.

Dr. Trowbridge kindly provided numerous papers of the Iowa Geological Survey and learned advice which has enabled me to study the history of the Pleistocene Epoch and to create this paper concerning the temporary Mississippi River. He has also obligingly read the manuscript before publication.

I also acknowledge the assistance of Dr. George E. Ekblaw who contributed reports concerning investigations conducted in northwestern Illinois by the Illinois Geological Survey. 
It is the purpose of this paper to present the results of studies made with special reference to the Illinoian and Wisconsin glacial stages. It is these glacial stages with which we are directly concerned as the Mississippi River was first diverted from its course by the advancing Illinoian ice sheet and again by the Wisconsin ice.

\section{The Great Ice Age}

The Pleistocene Epoch is distinguished chiefly by glaciation. Each subepoch represents a natural cycle of history, beginning with an expansion of glacier ice and the deposition of a drift. As the ice later wasted away, its deposits were exposed to stream dissection and chemical weathering. In time, a soil formed over the surface of the deposits, lakes and swamps were gradually filled by vegetation, and sediments and drainage was re-established. This orderly change was interrupted by the next advance of the ice, which spread a new sheet of till and started a new cycle. The many millions of square miles of ice still stored in Greenland and Antarctica show that we may not yet be completely out of the Ice Age.

The cause of an ice age is not clear but authorities agree that a mean annual temperature of about 14 degrees lower would initiate continental glaciation. There must also be snow. "Favorable conditions," states Dr. A. C. Trowbridge, "are low temperature and high precipitation. The problems of the causes of glaciation and especially the causes of multiple glacial and interglacial stages and substages are very complex and many theories have been advanced."

\section{Advance of GLaciers}

Tens and hundreds of thousands of years ago, most of North America was covered by huge glaciers which expanded from centers in central and eastern Canada. They developed when the mean annual temperatures were somewhat lower than now, so that not all of the snow that fell during the winters melted during the summers. The snow accumulated year after year until a sheet of ice was formed so thick that, as a result of its weight, it began to creep outward, carrying with it the soil and rocks on which it rested and over which it moved.

It is known that there were four major stages of glaciation during the Pleistocene or great Ice Age, in which great ice sheets invaded the northern portions of the Mississippi Valley, 
and three long interglacial intervals in which conditions were much as they are today. Present facts, obtained from many years of field investigation and laboratory work by many geologists indicate that, the Pleistocene Epoch began about one million years ago when the Nebraskan glacier advanced over the area. To appreciate the significance of Pleistocene history and its effects, we must consider the various glacial and interglacial stages of that epoch.

\section{Nebraskan Glactal Stage}

This is the oldest stage of the Pleistocene of Iowa. The drift deposited during this stage is known as Nebraskan drift, the name Nebraskan having been given to it by Bohumil Shimek, an Iowa geologist and botanist. The ice reached the west edge of the present Mississippi Valley but did not cross the river.

\section{Aftonian Interglacial Stage}

In 1928, Iowa geologists George F. Kay and Earl T. Apfel stated that, "Following the retreat of the Nebraskan ice sheet beyond the northern boundary of Iowa and far to the north, Iowa's Aftonian interglacial history began. The new Nebraskan drift surface which resulted from the advance and retreat of the Nebraskan continental ice sheet could not have remained uncovered for more than a very short time. Marginal vegetation undertook almost at once to occupy the new territory, and as soon as the climatic conditions became sufficiently congenial this vegetation no doubt spread rapidly over the surface."

\section{Kansan Glacial Stage}

The next glacial episode produced the Kansan glacier which again advanced from the northwest and pushed farther southwest of the Mississippi River than any other glacier before or after. The name Kansan was given by T. C. Chamberlin in 1894. This glaciation, as judged from the distribution of icedeposited materials, covered all of Iowa except a small area in the form of a narrow strip along the Mississippi River in the northeastern part of the state.

\section{YARMOUTH INTERGLaCiaL STAGE}

The name Yarmouth was introduced by Frank Leverett in 1898 and was applied first to the soil and weathered zone where the Illinoian overlies the Kansan till sheet between Davenport, Iowa, and Quincy, Illinois. The record of Yar- 
mouth life is very poorly representative of the fauna and flora which must have inhabited this area during the second interglacial stage.

\section{Illinolan Glacial Stage}

The Illinoian glacier was near its maximum extent when it reached the Mississippi River from the east on its long journey from the Labradorean center of dispersion. Therefore, it pushed over into Iowa only a few miles.

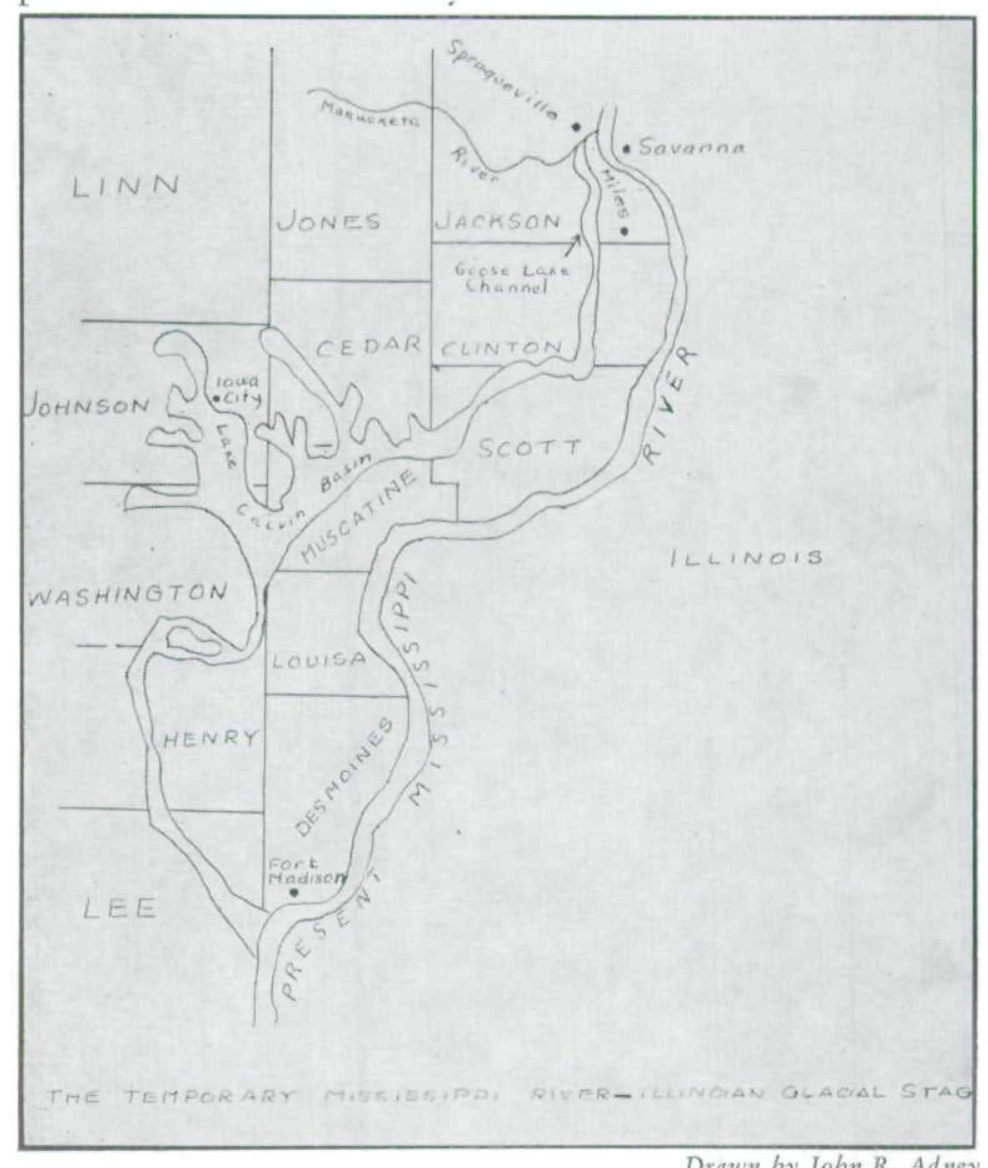

Sangamon Interglacial Stage

The name Sangamon was first used by A. H. Worthen for a soil zone which he described in a report on the geology of Sangamon County, Illinois, written in 1873. 
The present usage of the term Sangamon to denote the interglacial stage between Illinoian and Wisconsin glacial stages was introduced by Frank Leverett in 1898.

Because of the scarcity of fossiliferous deposits which can be definitely ascertained as Sangamon in age, little is known of the fauna and flora in Iowa of this interglacial stage, which is estimated to have lasted about 150,000 years.

Wisconsin Glacial Stage

The name East Wisconsin was first used by T. C. Chamberlin in 1894 for the most recent of the glacial stages of the Pleistocene epoch. The name was shortened in the following year to Wisconsin.

\section{The Temporary Mississippi River}

The course of the Mississippi River has been effected by several advancing ice sheets. The Nebraskan glacier displaced it to the east, the Kansan glacier shoved it farther east, the Illinoian glacier displaced it westward. When the Illinoian ice retreated, it took an eastward course again.

The Iowan, or Tazewell, ice in early Wisconsin glacial time forced it back into a western course. The Mississippi River was twice diverted into the present Goose Lake Channel in eastern Jackson County caused by the ponding of waters by advancing ice sheets, first during the Illinoian glacial stage, and again by the Iowan, or Tazewell, ice during the Wisconsin glacial stage.

Professor T. E. Savage, writing in 1905, informs us that, "The Goose Lake Channel, which the Maquoketa River follows from Spragueville to Green Island represents the temporary channel occupied by the Mississippi River during the portion, at least, of the Illinoian ice invasion.

When the lobe of this glacier pushed over into the southeast corner of Iowa from Illinois, the channel of the Mississippi River was blocked with ice, and its waters were forced to find a passage around the margin of the ice sheet. In seeking a new course to the west of the lobe of ice, the river left its pre-Illinoian channel at Green Island. It followed up the preexisting Maquoketa Valley to a point near the middle of Section 18 of Van Buren township. At this place the temporary Mississippi forsook the Maquoketa channel and continued 
southward, forming the broad valley which at present is partly occupied by Deep Creek."

In Jackson County, the bottom of the temporary Mississippi Valley was 20 to 25 feet higher than the present bed of the Maquoketa River in the same portion of its course, and was several feet above the bed of Deep Creek which now occupies the ancient valley in Sections 19,30 and 31 of Van Buren Township. "It seems probable," continues Professor Savage, "that the divide between the headwaters of Deep Creek, and Brophy's Creek in Clinton County, formed a barrier which the temporary Mississippi River never succeeded in cutting down to the level of the valley of the Maquoketa River in the vicinity of Spragueville." This is indicated by the fact that the present altitude of this divide where it is crossed by the temporary Mississippi channel a short distance south of Goose Lake, is about 665 feet above sea level, while ten miles farther north, the elevation of the flood plain of the Maquoketa River, near Spragueville, is not far from 660 feet above sea level. A bench of Niagara limestone that extends nearly across the channel in the northwest quarter of Section 19 of Van Buren township bears witness to the presence of some obstruction. The remnants of a terrace of fluvial materials, 25 feet in height that borders this old valley further south, in Sections 30 and 31, also point to some probable obstruction further down the valley. The presence of such a barrier possibly explains why the Mississippi River returned to its pre-Illinoian channel soon after the melting of the Illinoian ice sheet.

It also accounts in part for the fact that the Maquoketa River soon abandoned the course south from Spragueville, along the valley of the temporary Mississippi and again developed an outlet to its master stream towards the northeast between Spragueville and Green Island, in a direction of flow opposite to that of the temporary Mississippi River. A detailed discussion of the course of the temporary Mississippi after it left the borders of Jackson County will not be attempted. However, it has been determined by many years of field work by numerous geologists that, the waters in their southerly course, joined those of Wapsipinicon River, turned westward to the mouth of Mud Creek, and southward over the Mud-Elkhorn divide to the Cedar River at Moscow. The valley 
of the Iowa-Cedar rivers also was blocked by the same ice sheet on one side and by high blufts on the other.

Thence continuing southward to the junction of Iowa-Cedar rivers at Columbus Junction, the combined waters of the Mississippi, Maquoketa, Wapsipinicon, Cedar and Iowa rivers and those flowing from the ice edge rose until the entire lake basin was covered by a wide expanse of water.

J. A. Udden of Augustana College, in 1899, applies to this ancient body of water the term "Lake Calvin," in honor of its discoverer, Dr. Samuel Calvin, then director of the Iowa Geological Survey.

Although the history of Pleistocene investigation in the Lake Calvin region can be traced back as far as 1852 at the time David D. Owen published his "Report of a Geological Survey of Wisconsin, Iowa and Minnesota," no great progress had been made until about 1891, when W. J. McGee's classic report on "The Pleistocene History of Northeastern Iowa" appeared.

During the summer months of 1916 and 1917, field work and mapping in the lake basin and in practically the entire southern half of eastern Iowa was conducted by Walter H. Schoewe of the Iowa Geological Survey. His report, "The Origin and History of Extinct Lake Calvin," accompanied by numerous maps and illustrations was published in the 1919 and 1920 Annual Reports of the Iowa Geological Survey.

Geographically, extinct Lake Calvin lies in the southeastern part of Iowa. The site of this former expanse of water is confined chiefly to an area lying roughly parallel to Iowa and Cedar rivers, from Iowa City to Moscow in Johnson and Muscatine counties, respectively, in the north, to Columbus Junction, Louisa County, in the south. The Lake Calvin basin lies in the drainage systems of Iowa and Cedar rivers.

Old Man's creek, English river, Whisky Run, Davis and Goose creeks are the important tributaries of Iowa river, while Wapsipinicon and Mud Creek form the chief affluents of the Cedar. Schoewe's investigations led him to believe that Lake Calvin existed almost to the coming of the Iowan glacier and that the lake was drained in a comparatively short time. The lake covered an area of about 325 square miles, extended along the ice edge for almost fifty miles and of its maximum extent 
was approximately 720 feet above sea level. Schoewe informs us that, "No hypothesis regarding the draining of Lake Calvin has ever been advanced. It is obvious that the main factors in the draining of the ancient lake were the development of streams on the recently formed Illinoian gumbotil plain and stream piracy. Just where and how the piracy took place must remain hypothetical, as field evidence is lacking."

After the Illinoian ice sheet had withdrawn from the region a long time elapsed before erosion became active. During this time the drift was subjected to atmospheric weathering and erosion became active, due either to crustal deformation or to the fact that the region lies in close proximity to the master drainage lines. New streams tributary to Mississippi river north and south of the Illinoian area soon developed and worked their way headward into the Illinoian upland. Finally, some stream was able to work its way backward until Lake Calvin was tapped and drained. The water of the lake found its way to the unfilled valley of the Mississippi by a devious course through the now abandoned Leverett channel to the present valley of the Mississippi below Fort Madison and continued southward.

\section{Wisconsin ICE SHEet}

In the fourth or Wisconsin glacial stage, which is estimated to have started 50,000 to 70,000 years ago, the Green River lobe of Iowan, or Tazewell ice extended west of the Mississippi River to the eastern border of the Goose Lake channel and within 1 1/2 miles of the present village of Goose Lake, in Clinton County, Iowa. This took place about 17,000 years ago.

We should pause for a moment to refer to M. M. Leighton's differentiation of the drift sheets of northwestern Illinois. To the glacial geologist, this has been the most controversial part of the state. Leighton, in 1923, differentiated the glacial deposits of northwestern Illinois into two drift sheets in which his mapping differed notably from that of Frank Leverett's 1899 glacial map of this area. In so doing, he assigned the drift of the Polo, Dixon and Pecatonica areas, which Leverett and $\mathrm{O} . \mathrm{H}$. Hershey regarded as Iowan, to the Illinoian glacial stage; he assigned the Belvidere and Green River lobes to the Early Wisconsin glacial substage rather than to the Iowan glacial stage. The latter he did because the American classi- 
fication at that time recognized the Iowan glaciation as a separate and distinct glacial stage from the Wisconsin, the two supposedly being separated by an interglacial interval, the Peorian. Leighton looked for, but failed to find, evidence of such an interval, and therefore he concluded that the Belvidere and Green River drifts were Early Wisconsin, possibly an extension of the Shelbyville glaciation. In 1931, by a re-examination of the Farm Creek section near Peoria, he found that the concept of the Peorian interglacial age was unsoundly based. The Iowan loess had not been oxidized and leached before the deposition of the overlying Shelbyville till.

He concluded that the Iowan was actually a substage of the Wisconsin, which immediately preceded the Early Wisconsin. Had there not been this early error in glacial science in the classification of the Iowan, there would have been no reason for suggesting that the drift was Early Wisconsin. For this and other reasons, Leighton now refers this relatively fresh drift to the Iowan substage.

In 1954, P. R. Shaffer reported that the lowland which had persisted from pre-glacial time was present between Fulton, Illinois, and the Illinois River during the advance of the Tazewell ice. This lowland, a possible course of the pre-glacial Mississippi River, extended southeastward from Clinton, Iowa, through the Meredosia channel and Green River Basin to the "big bend" of the Illinois River near Bureau. Geologists had previously recognized that Lake Calvin, which formed in front of the western margin of the Illinoian ice in Iowa, was of short duration, and that following the retreat of the Illinoian ice, the upper Mississippi River drainage returned to its southeastward course to the Illinois River and continued there during the Sangamon interglacial stage. The presence of this broad valley in post Sangamon time facilitated the western extension of the Shelbyville ice. In the area between Fulton and Keokuk, two drainage systems operated during the Sangamon interglacial stage and the Iowan substage. The northern drainage flowed through the Meredosia channel, southeastward to the Illinois River in Bureau County. A tributary which headed in a rock divide just west of Andalusia flowed eastward and northward along the present Rock River Valley to join the old Mississippi. A divide also existed near Cordova 
from which a small stream flowed north to the old Mississippi and a stream flowed southwestward past Rock Island, Illinois, to join the stream in the lower Rock River Valley.

The southern drainage system included the Iowa and Skunk rivers which flowed southward through the Keokuk rock valley. With the beginning of Iowan, or Tazewell, glaciation, the first blocking of the northern drainage system occurred at the "big bend" of the present Illinois River. Here, the ice ponded the old Mississippi to form the first stage of a glacial lake, called Lake Milan.

The lake, which in the initial stage extended from the Illinois River to the outlet over the rock divide west of Andalusia, was later restricted to the lower Rock River Valley when the ice reached the western walls of the present Rock River Valley. When the Iowan, or Tazewell, ice reached the west wall of the Rock River Valley southeast of Cordova, glacial Lake Cordova was formed. Glacial Lake Milan was then restricted to the lower Rock River Valley and received meltwater from the ice, which may have already reached Geneseo, Illinois, or was advancing toward Geneseo from the east. The level of glacial Lake Cordova subsequently rose about 15 feet; the waters spilled over the divide near Cordova and cut the Cordova gorge. When the Early Wisconsin ice crossed the Mississippi Valley into eastern Iowa, glacial Lake Savanna formed north of Fulton, Illinois. The outflow of this lake was by way of the Maquoketa River bay, through the Goose Lake channel to the Wapsipinicon, and through the Cordova Valley. The waters of glacial Lake Savanna joined those of glacial Lake Milan (restricted), flowed through the rock valley west of Andalusia, and lowered the outlet fairly rapidly.

With the lowering of this outlet, the intrenchment of the Cordova gorge and the withdrawal of the Green River lobe to the east, the two drainage systems were integrated to form the present Mississippi River Valley between Fulton and Keokuk.

\section{Conclusion}

The present Goose Lake Valley drains a strip of the uplands on either side, a little less than two miles in width. The bottom of the valley has a very sluggish drainage, with a slope of only five feet to the mile in either direction north and south, 
from the divide one mile south of Goose Lake. The greater portion of its surface was formerly marshy, but a considerable area has since been reclaimed by artificial drainage.

Since the time the channel was abandoned by the stream that made it, accumulations of silt have raised its bottom, which once had a general slope to the south. At present its surface slopes to the north from the point near Goose Lake, and is drained in that direction by Deep Creek.

Will the ice return? No one can answer this, but future geologists will not be surprised if it does. If the ice comes, it will not suddenly overwhelm us, but will creep slowly down from northern Canada over a period of thousands of years. The people of future generations should have sufficient time to relocate cities in what will become the rainy lower latitudes. The land surface might again be ice-covered to the Missouri and Ohio rivers.

Excerpts from "Pen and Scissors," Iowa State Register, Des Moines, Tuesday, September 20, 1881.

The Princess of Wales has not patronized the crinolette.

Baby sashes, tied high in the back, are adopted by young ladies.

The Canada papers intimate that Lord Lorne takes his tipple pretty regularly.

The most beautiful woman at Saratoga this season is said to have been a circus rider.

London doctors say that Little Princess bonnet promotes earache and neuralgia.

Josie Mansfield, the woman for whom Jim Fiske was killed, is said to be keeping a gambling house in Paris.

Chicago and New Orleans are the only American cities that licensed gambling houses. St. Louis is about to follow their example.

A Mexican says that the government of the United States is less reliable than that of Mexico and has more disturbing elements. 
Copyright of Annals of Iowa is the property of State of Iowa, by \& through the State Historical Society of Iowa and its content may not be copied or emailed to multiple sites or posted to a listserv without the copyright holder's express written permission. However, users may print, download, or email articles for individual use. 